\title{
Postpolypectomy syndrome presenting with "microperforation" and pneumoperitoneum: conservative approach for a rare cause of acute abdominal pain
}

\author{
Síndrome pospolipectomía de presentación como "microperforación" y \\ neumoperitoneo: abordaje conservador para una rara causa de \\ dolor abdominal
}

Anwar Medellín', Eric E. Vinck², Luis Cabrera², Tim Peterson³

Department of Colorectal Surgery; Universidad Militar Nueva Granada. Bogotá, Colombia

2 Department of Surgery; Universidad El Bosque. Bogotá, Colombia

3 Department of Surgery; Universitair Ziekenhuis Brussel - VUB, FACS. Universitair Ziekenhuis Brussel, Jette, Bélgica

\section{Resumen}

Introducción. El Síndrome Pospolipectomía es una causa rara de dolor abdominal posterior a resecciones de pólipos por colonoscopia, cuyo caso, en ciertos pacientes se debe considerar el manejo conservador.

Métodos. Se revisa la literatura sobre el síndrome en mención y se reporta un caso.

Resultados. Nuestra paciente presentó con cuadro de dolor abdominal posterior a una polipectomía colonoscópica, tratado mediante un manejo conservador con base en los hallazgos clínicos, tomográficos y paraclínicos. Su recuperación fue favorable y no requirió intervenciones adicionales.

Conclusiones. El manejo conservador con líquidos endovenosos, antibióticos y suspensión de vía oral puede ser una opción en pacientes con síndrome pospolipectomía incluso, en contexto de "micro-perforaciones" cuando no haya irritación peritoneal.

Palabras clave: pólipos del colon; colonoscopía; resección endoscópica de la mucosa; perforación intestinal; tratamiento conservador.

\begin{abstract}
Post-polypectomy syndrome is a rare cause of acute abdominal pain following colonoscopic polyp resections. Conservative treatment may be considered in selected patients. We present a literature review of Post-polypectomy syndrome and report a case and our experience with a young female who presented with an acute abdominal pain following a colonoscopic polypectomy. We selected a conservative approach based on clinical findings, lab tests and CT results; the patient had complete recovery and no additional intervention was required. Conservative treatment with IV fluids, nothing by mouth and antibiotics can be an alternative treatment plan for selected patients with mini-perforations presenting without peritoneal irritation.

Key words: colonic polyps; colonoscopy; endoscopic mucosal resection; intestinal perforation; conservative treatment.

Fecha de recibido: 09/01/2018 - Fecha aceptación: 18/04/2018

Correspondencia: Eric E. Vinck, MD, E-mail: evinck518@gmail.com, Bogotá, D.C.

Citar como: Medellin A, Vinck EE, Cabrera L, Peterson T. Post-polypectomy Syndrome presenting with "micro-perforation" and pneumoperitoneum: Conservative approach for a rare cause of acute abdominal pain. Rev Colomb Cir. 2018;33:318-22. https://doi. org/10.30944/20117582.78
\end{abstract}




\section{Introduction}

Post-polypectomy coagulation syndrome (PPCS), also known as post-polypectomy syndrome or transmural burn syndrome, is defined as the development of abdominal pain, fever, leukocytosis, and peritoneal inflammation in the absence of frank perforation that occurs after colonoscopic polypectomy with electrocoagulation. It is a known but uncommon complication following colonoscopic polyp resections. Its incidence ranges between 0.5 and $1.5 \%$ and symptoms may appear as soon as 12 hours and up to 5 days following colonoscopy. Common signs include abdominal pain (88\%), fever (65\%), leucocytosis (59\%), increased C-reactive protein and peritoneal irritation. When free peritoneal air or acute abdomen is present, colonic perforation should be considered; which has an incidence of $0.11 \%$ following colonoscopic polypectomies. When treatment involves surgery, mortality rate approaches of $3 \%$ in some series. ${ }^{(2-5)}$ The term "miniperforation" refers to small colonic perforations which present without peritoneal irritation and pneumoperitoneum is seen on diagnostic imaging. Differentiating "mini-perforations" from frank perforations is vital to establishing the appropriate treatment, whether conservative or surgical. Here we present the case of a patient with PPS along with "micro-perforation" and pneumoperitoneum managed conservatively with a literature review. ${ }^{(1-7)}$

\section{Case report}

A 29 year-old female without significant clinical histories besides an appendectomy, presents with a clinical picture of 8 hours of moderate generalized abdominal pain following a programmed colonoscopic $12 \mathrm{~mm}$ sigmoidal polyp resection. At presentation the patient denied vomiting or fever, physical examination showed generalized abdominal pain without rebound tenderness or signs of peritoneal irritation along with mild distention. Vital signs showed a II5/70 $\mathrm{mmHg}$ blood pressure, 75 bpm heart rate, 37.I degrees Celsius, temperature and $92 \%$ oxygen saturation. Blood work showed normal renal function, coagulation and electrolytes, with significant leukocytosis of 24.830, neutrophils $90,9 \%$ along with a C-Reactive Protein of $124 \mathrm{mg} / \mathrm{L}$ and normal hemoglobin levels. Arterial blood gases showed no acid-base abnormalities or elevated levels of lactate. The patient was first seen by the emergency medical team, which ordered chest and abdominal x-rays that exhibited no signs of intestinal obstruction or pneumoperitoneum. (Figure I and 2).

Taking the patient's stability and absence of peritoneal irritation into account, we chose a conservative approach and started intravenous fluid therapy, analgesics, gastric protection, antibiotics (piperacillin-tazobactam). Abdominal CT showed alteration of mesenteric fat tissue around the distal third of the descending colon and the proximal sigmoid, as well as adjacent air levels indicating pneumoperitoneum around the left hepatic lobe and para-colic mesenteric air (Figures 3 and 4).

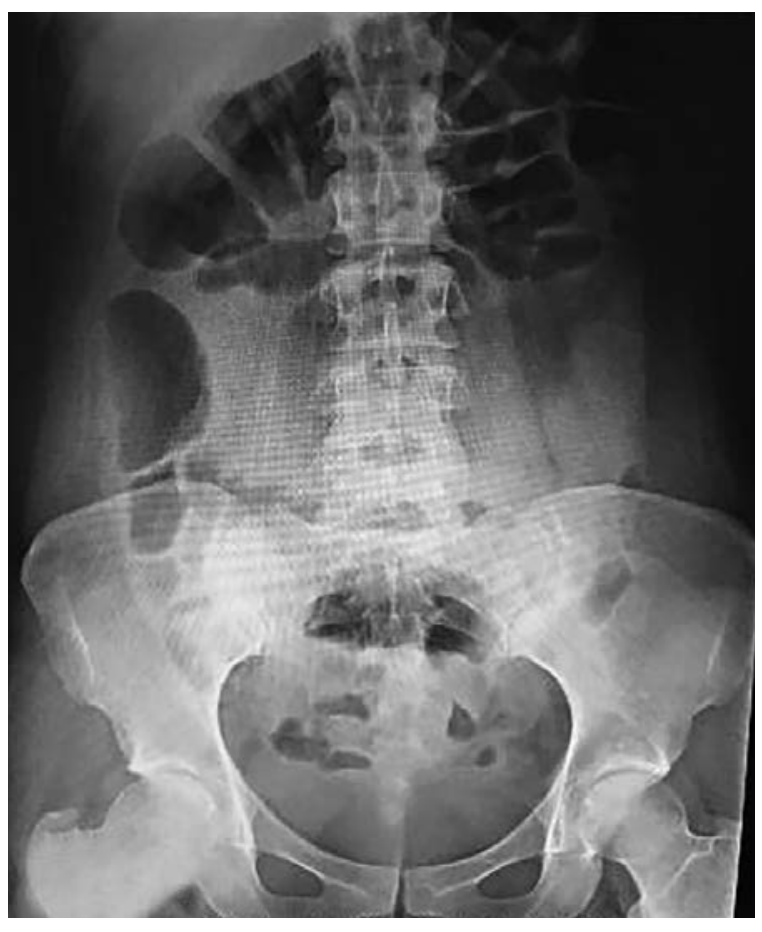

Figure 1. Abdominal radiography of the patient showing mildly distended intestinal lumen with presence of distal air without any sings of free air or obstruction. 


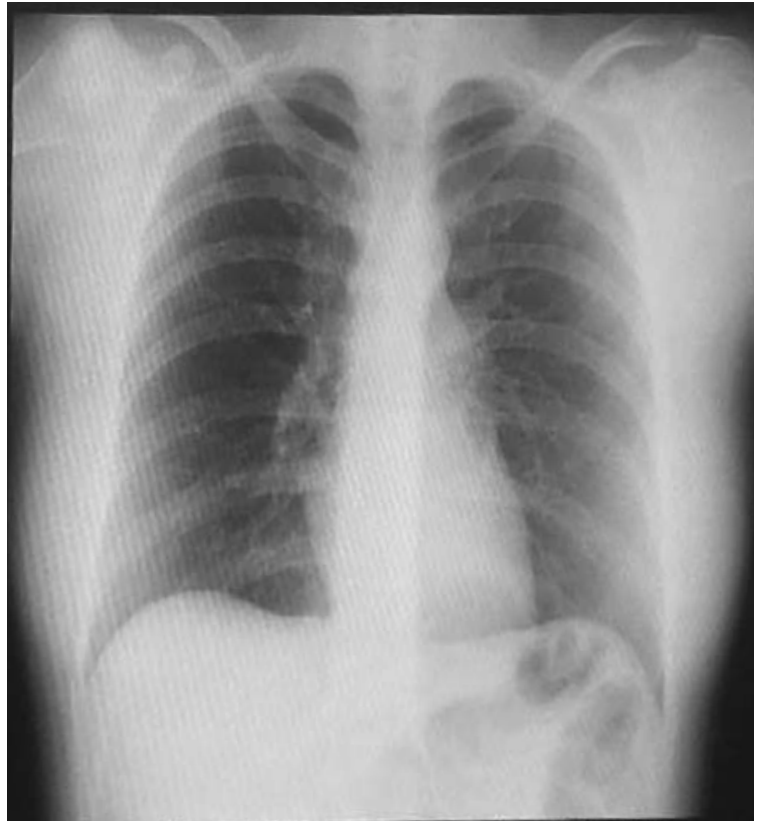

Figure 2. A chest radiography showing absence of free peritoneal air without any pleural alterations or diaphragmatic elevation.

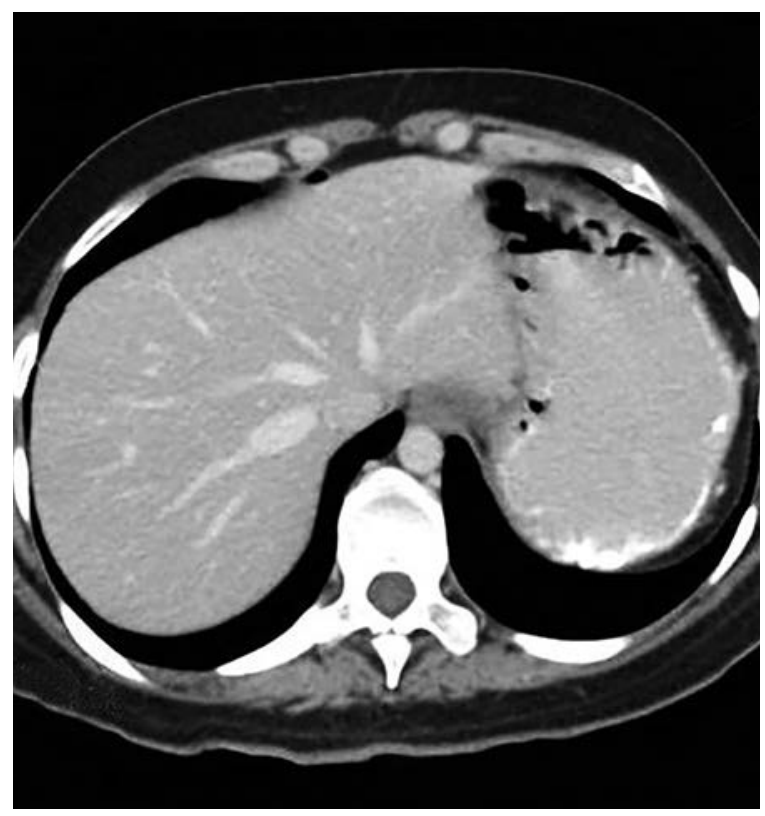

Figure 3. Contrast abdominal CT scan showing a small perihepatic laminar pneumoperitoneum without any free fluid in the abdominal cavity.

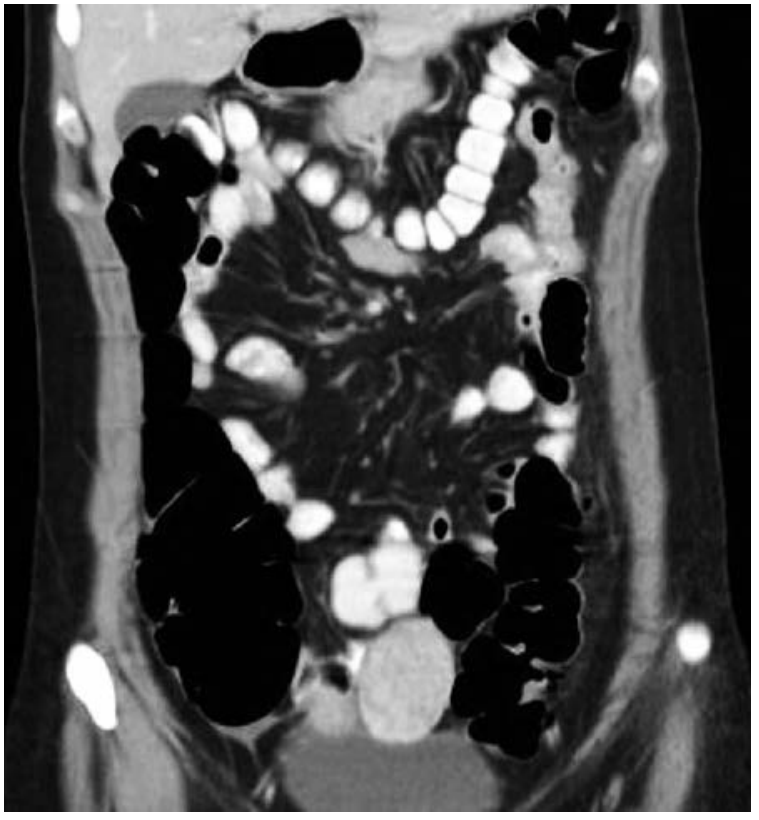

Figure 4. The patient's contrast abdominal CT scan showing free mesenteric para-colic air without free fluid in the peritoneal cavity.

During five days of in hospital observation the patient had progressive decrease of CBC with leukocytes of II.Ooo, stable hemoglobin levels and was given oral nutrition. At day 7 , the patient had adequate oral tolerance, intestinal transit as well as significant decrease in abdominal discomfort, and was discharged. Fifteen days following discharge expressed no abdominal pain and had adequate intestinal transit. Pathology report 2 weeks post-resection showed a tubulovillous adenoma with low grade dysplasia. The patient was seen once more at 8 weeks following discharge and no further interventions were necessary.

\section{Discussion}

Post-polypectomy syndrome appears when there is transmural burn and serosal inflammation leading to abdominal pain referred by patients on admission. In absence of perforation, surgery is rarely needed. Our patient presented with a micro-perforation and was managed as a perforated diverticulum with pneumoperitoneum. 
Risk factors include right-sided polyps (83\%) because of thinner mucosa, polyps larger than $2 \mathrm{~cm}$, and arterial hypertension (believed to be due to endothelial dysfunction). However, our patient did not have any of the usual risk factors. The diagnosis of PPS is in general a clinical diagnosis; abdominal tomography may discard or confirm free peritoneal air. Management is determined by the presence of peritoneal irritation, hemodynamic stability and the individual surgeon's preference. However, in the absence of acute abdomen and hypotension, conservative management should be considered whenever possible, even when perforation is suspected. Most small perforations presenting without acute abdomen usually resolve spontaneously due to omental adherence, thus surgical treatment is not always necessary. ${ }^{(4-9)}$ When conservative treatment is chosen, strict clinical observation is vital. Patients should be given IV antibiotics covering intestinal flora, follow-up CBC and C-reactive protein, IV fluids to prevent dehydration and electrolyte imbalance, analgesics and nothing by mouth for at least 72 hours. A 5-day in-hospital observation is recommended, as was managed our case. Symptoms usually resolve within 5-7 days and outpatient surveillance should be considered. Literature review shows that free peritoneal air on CT is a known predictor of failure of non-surgical treatment; however, other authors have described success cases in certain patients without hemodynamic instability. ${ }^{(5-8)}$ Thus medical management is feasible in stable patients, however when large amounts of free peritoneal air is present, failure rates reach $57-60 \%$. ${ }^{(5-8)}$ In one study conducted by Dharmarajan et al ${ }^{(13-14)}, \mathrm{I} 36$ patients presented with perforated diverticulitis, and only $5(3.7 \%)$ required emergency surgery on admission, 7 (5\%) required emergency surgery for failed conservative treatment; non-operative treatment in those presenting with free air was successful in (92.5\%) of patients. Sallinen et al ${ }^{(13-14)}$ reported that in 132 patients with perforated diverticula, $99 \%$ were treated successfully without surgery in absence of pericolic abscess and $62 \%$ were managed successfully non-operatively in the presence of distant intraperitoneal air. Free fluid in the Douglas fossa was a clear risk factor for failure, thus success rate for patients treated nonoperatively without risk factors was $86 \%$. When stable, patients taken to surgery should be treated with intestinal resection and anastomosis with or without stoma whereas in unstable patients, a Hartmann resection should be chosen. (6-14) With our patient conservative management was chosen because of hemodynamic stability, absence of peritoneal irritation and a general acceptable condition, even though free peritoneal air confirmed "micro-perforation". Our patient had complete recovery following careful in-hospital observation, IV antibiotics and nothing by mouth; after 5 days a liquid diet was ordered and adequate tolerance and intestinal transit suggested appropriate intestinal lumen healing and the patient was thus discharged. PPS is a rare complication of colonoscopy polyp resections, when accompanied by pneumoperitoneum, patients can be managed conservatively depending on the presence or absence of peritoneal irritation and hemodynamic stability. In patients presenting with peritoneal irritation with frank acute abdomen or hypotension, exploratory surgery is necessary, however, in stable patients without acute abdomen conservative treatment may be considered. Choosing the right management plan requires careful analysis of each patient, but in selected patients conservative treatment may avoid unnecessary surgical intervention.

\section{Interest conflict}

None.

\section{References}

I. Shin YJ, Kim YH, Lee KH, Lee YJ, Park JH. CT findings of post-polypectomy coagulation syndrome and colonic perforation in patients who underwent colonoscopic polypectomy. Clinical radiology. 20I6;7I(I0):I030-6. doi: IO.IoI6/j.crad.20I6.03.0Io.

2. Cha JM, Lim KS, Lee SH, Joo YE, Hong SP, Kim TI, Kim HG, Park DI, Kim SE, Yang DH, Shin JE. Clinical outcomes and risk factors of post-polypectomy coagulation syndrome: A multicenter, retrospective, case-control study. Endoscopy. 2013 (03):202-7. doi: I0.IO55/s-0032-I326IO4.

3. Christie JP, Marrazzo J. "Mini-perforation" of the colon-not all postpolypectomy perforations re- 
quire laparotomy. Diseases of the colon \& rectum. 1991;34(2):132-5.

4. Hirasawa K, Sato C, Makazu M, Kaneko H, Kobayashi R, Kokawa A, Maeda S. Coagulation syndrome: delayed perforation after colorectal endoscopic treatments. World journal of gastrointestinal endoscopy. 20I5;7(I2):IO55. doi: I0.4253/wjge.v7.i12.IO55.

5. Dib J. Post-Polypectomy Syndrome. The American Journal of Gastroenterology. 20I7;II2(2):390. doi :I0.IO38/ ajg.20I6.475.

6. Sartelli M, Catena F, Ansaloni L, Coccolini F, Griffiths EA, Abu-Zidan FM, Di Saverio S, Ulrych J, Kluger Y, Ben-Ishay O, Moore FA. WSES Guidelines for the management of acute left sided colonic diverticulitis in the emergency setting. World Journal of Emergency Surgery. 20I6;II(I):37. . doi: I0.II86/sI30I7-0I6-0095-0.

7. Fantozzi MA. Sindrome Post-polipectomia endoscópica. Rev. argent. coloproctología. 2009;20(I):23-6.

8. Benson BC, Myers JJ, Laczek JT. Postpolypectomy electrocoagulation syndrome: a mimicker of colonic perforation. Case Rep Emerg Med. 2013;2013. doi: IO.II55/20I3/68793I.

9. Thirumurthi S, Raju GS. Management of polypectomy complications. Gastrointestinal endoscopy clinics of North America. 20I5 Apr 30;25(2):335-57.
Io. Jehangir A, Bennett KM, Rettew AC, Fadahunsi O, Shaikh B, Donato A. Post-polypectomy electrocoagulation syndrome: a rare cause of acute abdominal pain. Journal of community hospital internal medicine perspectives. J Community Hosp Intern Med Perspect. 2015;5(5):29147. doi: I0.3402/jchimp.v5.29147.

II. Anderloni A, Jovani M, Hassan C, Repici A. Advances, problems, and complications of polypectomy. Clin Exp Gastroenterol. 2014;7:285-96. doi: I0.2I47/CEG.S43084.

I2. Ma MX, Bourke MJ. Complications of endoscopic polypectomy, endoscopic mucosal resection and endoscopic submucosal dissection in the colon. Best Pract Res Clin Gastroenterol. 2016;30:749-67.

I3. Sallinen VJ, Mentula PJ, Leppäniemi AK. Nonoperative management of perforated diverticulitis with extraluminal air is safe and effective in selected patients. Dis Colon Rectum. 20I4;57:875-8I. doi: IO.I097/ DCR.0000000000000083.

I4. Dharmarajan S, Hunt SR, Birnbaum EH, Fleshman JW, Mutch MG. The efficacy of nonoperative management of acute complicated diverticulitis. Diseases of the Colon Rectum. 20II;54:663-7I. doi: I0.IO07/ DCR.obor3e31820ef 759 . 